\title{
Designing Open-Ended Experiments by Integrating Courses: An Experience
}

\author{
Deepak Yaraguppi ${ }^{1}$, Sharanappa A ${ }^{2}$, Laxmikant R Patil ${ }^{3}$, Veeranna S Hombalimath ${ }^{4}$ and Nagaraj Ekbote ${ }^{5}$ \\ 1,2,3,4,5 Department of Biotechnology, BVB College of Engineering and Technology, Hubli \\ 12deepak.yaraguppi@gmail.com, deepak.yaraguppi@bvb.edu \\ ${ }^{2}$ sharanappaa@bvb.edu \\ ${ }^{3}$ Irpatil@bvb.edu \\ ${ }^{4}$ hombalimath@bvb.edu \\ ${ }^{5}$ nagaraj_ekbote@bvb.edu
}

\begin{abstract}
Integration in teaching and learning approach is required due to increasing use of emergent technologies in research and industry. Integration learning helps students to visualize exact picture of industry. In case of Bachelor of Engineering in Biotechnology, integration of subjects and labs increases their knowledge and get the whole process of bio production. The present work synthesizes the outcomes of integrated learning in Downstream Process Technology lab (DSPT lab) and Bioprocess Engineering lab. Openended experiment was given to seventh semester students and anticipated to use the knowledge of bioprocess engineering lab and DSPT lab to complete the task. Openended experiment illustrates the flow of processes in Bioprocess industry which involves production of proteins and metabolites. As a result students could relate and use the knowledge learnt in each other lab to complete the task. Performance of the students was assessed as per Accreditation Board for Engineering and Technology's (ABET) $3 b$ \& $3 g$ criteria.
\end{abstract}

3b- Design and conduct experiment $3 g$-Communicate effectively

Keywords: Integrated learning, DSPT lab, Bioprocess Engineering lab, Open ended experiment

\footnotetext{
Deepak Yaraguppi ${ }^{1}$

${ }^{1}$ Department of Biotechnology, BVB College of

Engineering and Technology, Hubli

${ }^{1}$ deepak.yaraguppi@gmail.com
}

\begin{abstract}
Introduction:
An open-ended lab is where students are given the freedom to develop their own experiments, instead of merely following the already set guidelines from a lab manual or elsewhere. Making labs open-ended pushes students to think for themselves and think harder. Open-ended laboratory classes can be broadly defined as classes where the students are encouraged to design their own experiments or devise their own experimental strategy, rather than required to follow a rigid set of experimental guidelines specified elsewhere as in a lab manual. The students here have to devise their own strategies and back them with explanations, theory and logical justification [Strategies for Effective Teaching]. This not only encourages students to come up with their experiments, but requires them to defend themselves and their experiment, if questioned. It is an important topic based on emergent technologies. In our prespective its use in education is essential because everyone will involve in this activity. In this study openended experiment is performed in Dowstream Process Technology Laboratory (DSPT lab). Students of seventh semester who performed this activity have studies Bioprocess Engineering and Downstream Process Technology theory. Even they have Bioprocess Laboratory this semester. DSPT lab involves processes that concentrate the end product of ferementation. In order to make students understand the activities involved in Bioprocess industry, we decided to combine Bioproces lab and DSPT lab and give openended experiment in DSPT lab. We are proposing an effective assessment strategy to measure the effectiveness of open-ended on $3 \mathrm{~b}$ and $3 \mathrm{~g}$ ABET criteria. [2] [6] [7]
\end{abstract}

\section{Methodology:}

Team Formation: For seventh semester students batches were being made prior to start of semster, like batch1, batch2, batch 3 and batch4. Bioprocess Engineering lab and DSPT lab were being carried out in these batches. Same 
batches were being formed while giving the open ended topic. They were being informed to carry out the experiment in these batches. Each batch consisted of 12 students. Each and every student of the batch has to work on achieving the goal of solving the open-ended task.

Open-ended Task: Student batches were given the task to produce and purify lipase enzyme from Bacillus species. The batches were sanctioned complete freedom in choosing the equipment, experimental parameters, and the data analysis methods. We acted as consultants, giving hints and suggestion. As expected, students faced many problems forcing the students to come out with innovative means to solve the problem. For example, how to purify the end product and analyze it.

Methodology for Assessment: Students were given with task of performing an experiment to meet the objective. Rubrics for assessment were made in order to assign marks for individual students of the group. Rubrics were designed in such a way that it addresses both the criteria i.e $\mathrm{b}$ and $\mathrm{g}$. the rubrics for assessment is as shown below [6]

\begin{tabular}{|c|c|c|c|}
\hline PIs & \begin{tabular}{|l} 
Exceptional \\
$\mathbf{7 5 - 1 0 0 \%}$ \\
\end{tabular} & \begin{tabular}{|l} 
Acceptable \\
$\mathbf{5 0 - 7 4 \%}$
\end{tabular} & $\begin{array}{l}\text { Marginal 0- } \\
49 \%\end{array}$ \\
\hline$\left|\begin{array}{ll}\text { Select } & \\
\text { appropriate } \\
\text { equipment } & \& \\
\text { tools } & \text { to } \\
\text { meet } & \text { desired } \\
\text { needs } & \\
\text { OE (b) } & -1 \text { B }\end{array}\right|$ & $\begin{array}{l}\text { All materials } \\
\text { and the setup } \\
\text { used in the } \\
\text { experiment are } \\
\text { clearly and } \\
\text { accurately listed }\end{array}$ & $\begin{array}{l}\text { Most of the } \\
\text { materials and } \\
\text { the setup used } \\
\text { in the } \\
\text { experiment } \\
\text { are accurately } \\
\text { listed }\end{array}$ & $\begin{array}{l}\text { Many } \\
\text { materials are } \\
\text { listed } \\
\text { inaccurately }\end{array}$ \\
\hline $\begin{array}{l}\text { Use } \\
\text { laboratory } \\
\text { instruments } \\
\text { following } \\
\text { Standard } \\
\text { Operating } \\
\text { Procedure } \\
\text { (SOP). } \\
\text { OE (b) -2A }\end{array}$ & $\begin{array}{l}\text { Procedures are } \\
\text { listed in clear } \\
\text { steps; each step } \\
\text { is } \\
\text { numbered and } \\
\text { in a } \\
\text { complete } \\
\text { sentence; the } \\
\text { experiment } \\
\text { could be easily } \\
\text { replicated based } \\
\text { on the } \\
\text { procedures } \\
\text { provided }\end{array}$ & $\begin{array}{l}\text { Procedures } \\
\text { are listed, but } \\
\text { seem to be } \\
\text { missing some } \\
\text { information } \\
\text { that would } \\
\text { allow one to } \\
\text { successfully } \\
\text { replicate the } \\
\text { experiment; } \\
\text { some steps } \\
\text { are not } \\
\text { numbered } \\
\text { and/or are in } \\
\text { incomplete } \\
\text { sentences } \\
\end{array}$ & $\begin{array}{l}\text { Procedures } \\
\text { do not } \\
\text { accurately } \\
\text { list the steps } \\
\text { of the } \\
\text { experiment }\end{array}$ \\
\hline $\begin{array}{l}\text { Record the } \\
\text { data in the } \\
\text { required } \\
\text { format } \\
\text { OE (b) }-2 C\end{array}$ & $\begin{array}{l}\text { Lab report is } \\
\text { typed/written } \\
\text { using the } \\
\text { appropriate } \\
\text { format } \\
\text { specified }\end{array}$ & $\begin{array}{l}\text { Lab report is } \\
\text { mostly } \\
\text { typed/written } \\
\text { using the } \\
\text { appropriate } \\
\text { format, but } \\
\text { revisions are } \\
\text { necessary }\end{array}$ & $\begin{array}{l}\text { Lab report is } \\
\text { not } \\
\text { typed/written } \\
\text { using the } \\
\text { appropriate } \\
\text { format }\end{array}$ \\
\hline
\end{tabular}

\begin{tabular}{|c|c|c|c|}
\hline $\begin{array}{l}\text { Ability to } \\
\text { write } \\
\text { laboratory } \\
\text { reports, } \\
\text { including } \\
\text { figures, } \\
\text { tables and } \\
\text { graphs } \\
\text { OE (g) -1B }\end{array}$ & $\begin{array}{l}\text { Professional } \\
\text { looking and } \\
\text { accurate } \\
\text { representation } \\
\text { of the data in } \\
\text { tables, } \\
\text { graphs, and } \\
\text { written form; } \\
\text { graphs and } \\
\text { tables } \\
\text { areappropriately } \\
\text { labeled and } \\
\text { titled }\end{array}$ & $\begin{array}{l}\text { Accurate } \\
\text { representation } \\
\text { of the data in } \\
\text { two of the } \\
\text { three possible } \\
\text { forms } \\
\text { (written, } \\
\text { graphs, } \\
\text { tables); } \\
\text { graphs or } \\
\text { tables are not } \\
\text { appropriately } \\
\text { labeled and } \\
\text { titled, } \\
\text { something is } \\
\text { missing }\end{array}$ & \begin{tabular}{|l|} 
Data are \\
inaccurate \\
and/or \\
represented \\
in \\
only one of \\
the three \\
possible \\
forms \\
(written, \\
graph, \\
tables), a lot \\
is \\
missing
\end{tabular} \\
\hline $\begin{array}{l}\text { Verify and } \\
\text { conclude } \\
\text { experimental } \\
\text { results } \\
\text { OE (b) -3D }\end{array}$ & $\begin{array}{l}\text { Conclusion } \\
\text { includes } \\
\text { summary of the } \\
\text { experiment, } \\
\text { whether the } \\
\text { findings } \\
\text { supported the } \\
\text { hypothesis, } \\
\text { possible } \\
\text { sources of error, } \\
\text { and what was } \\
\text { learned from the } \\
\text { experiment }\end{array}$ & \begin{tabular}{|l} 
Conclusion \\
includes a \\
general \\
overview of \\
the \\
experiment \\
and what was \\
learned from \\
the \\
experiment; \\
something is \\
missing
\end{tabular} & $\begin{array}{l}\text { Conclusion } \\
\text { shows little } \\
\text { effort and } \\
\text { reflection, a } \\
\text { lot is missing }\end{array}$ \\
\hline
\end{tabular}

Table1: Rubrics for assessment of students

Depending on the work and report of each student marks were allotted based on the rubrics in the above table.

\section{Results and Discussion:}

Students were given with the task and analysis of their work was a task for us, which we performed using ABET a-k criteria. Experiment which our students performed was addressing $b$ and $g$ criteria of ABET where $b$ stands for ability to design and conduct experiments, analyze and interpret data and $\mathrm{g}$ stands for ability to communicate effectively. We analyzed the results

\begin{tabular}{|c|c|c|c|c|c|c|}
\hline $\begin{array}{l}\text { Student } \\
\text { USN }\end{array}$ & $\begin{array}{l}\mathrm{OE} \\
(\mathrm{b})- \\
1 \mathrm{~B}\end{array}$ & $\begin{array}{l}\mathrm{OE} \\
\text { (b) - } \\
2 \mathrm{~A}\end{array}$ & $\begin{array}{l}\mathrm{OE} \\
(\mathrm{b})- \\
2 \mathrm{C}\end{array}$ & $\begin{array}{l}\text { OE } \\
\text { (b) } \\
- \\
3 \mathrm{D}\end{array}$ & $\begin{array}{l}\mathrm{OE} \\
(\mathrm{g})- \\
1 \mathrm{~B}\end{array}$ & Total \\
\hline $\begin{array}{l}\text { 2BV09BT01 } \\
6\end{array}$ & 2 & 3 & 2 & 2 & 3 & 12 \\
\hline $\begin{array}{l}\text { 2BV09BT02 } \\
7\end{array}$ & 4 & 3 & 3 & 3 & 3 & 16 \\
\hline $\begin{array}{l}\text { 2BV10BT01 } \\
5\end{array}$ & 2 & 2 & 2 & 2 & 2 & 10 \\
\hline $\begin{array}{l}\text { 2BV11BT00 } \\
1\end{array}$ & 2 & 2 & 2 & 2 & 2 & 10 \\
\hline $\begin{array}{l}\text { 2BV11BT00 } \\
4\end{array}$ & 4 & 4 & 4 & 4 & 4 & 20 \\
\hline $\begin{array}{l}\text { 2BV11BT00 } \\
5\end{array}$ & 3 & 4 & 3 & 4 & 4 & 18 \\
\hline
\end{tabular}




\begin{tabular}{|c|c|c|c|c|c|c|}
\hline $\begin{array}{l}\text { 2BV11BT00 } \\
6\end{array}$ & 4 & 4 & 4 & 4 & 3 & 19 \\
\hline $\begin{array}{l}\text { 2BV11BT00 } \\
7\end{array}$ & 4 & 4 & 3 & 3 & 3 & 17 \\
\hline $\begin{array}{l}\text { 2BV11BT00 } \\
8\end{array}$ & 3 & 4 & 4 & 3 & 3 & 17 \\
\hline $\begin{array}{l}\text { 2BV11BT01 } \\
0\end{array}$ & 4 & 3 & 4 & 4 & 4 & 19 \\
\hline $\begin{array}{l}\text { 2BV11BT01 } \\
1\end{array}$ & 4 & 3 & 3 & 4 & 4 & 18 \\
\hline $\begin{array}{l}\text { 2BV11BT01 } \\
2\end{array}$ & 4 & 4 & 3 & 4 & 4 & 19 \\
\hline $\begin{array}{l}\text { 2BV11BT01 } \\
4\end{array}$ & 3 & 3 & 4 & 3 & 4 & 17 \\
\hline $\begin{array}{l}\text { 2BV11BT01 } \\
5\end{array}$ & 3 & 3 & 4 & 3 & 4 & 17 \\
\hline $\begin{array}{l}\text { 2BV11BT01 } \\
6\end{array}$ & 3 & 3 & 4 & 4 & 4 & 18 \\
\hline $\begin{array}{l}\text { 2BV11BT01 } \\
7\end{array}$ & 3 & 3 & 4 & 4 & 4 & 18 \\
\hline $\begin{array}{l}\text { 2BV11BT01 } \\
8\end{array}$ & 3 & 3 & 4 & 4 & 4 & 18 \\
\hline $\begin{array}{l}\text { 2BV11BT01 } \\
9\end{array}$ & 3 & 3 & 4 & 4 & 4 & 18 \\
\hline $\begin{array}{l}\text { 2BV11BT02 } \\
0\end{array}$ & 3 & 3 & 4 & 4 & 4 & 18 \\
\hline $\begin{array}{l}\text { 2BV11BT02 } \\
1\end{array}$ & 3 & 3 & 4 & 3 & 4 & 17 \\
\hline $\begin{array}{l}\text { 2BV11BT02 } \\
2\end{array}$ & 4 & 4 & 4 & 3 & 4 & 19 \\
\hline $\begin{array}{l}\text { 2BV11BT02 } \\
5\end{array}$ & 3 & 3 & 4 & 3 & 4 & 17 \\
\hline $\begin{array}{l}\text { 2BV11BT02 } \\
6\end{array}$ & 3 & 3 & 4 & 3 & 4 & 17 \\
\hline $\begin{array}{l}\text { 2BV11BT02 } \\
9\end{array}$ & 3 & 3 & 4 & 3 & 4 & 17 \\
\hline $\begin{array}{l}\text { 2BV11BT03 } \\
1\end{array}$ & 3 & 3 & 4 & 3 & 4 & 17 \\
\hline $\begin{array}{l}\text { 2BV11BT03 } \\
2\end{array}$ & 3 & 3 & 4 & 3 & 4 & 17 \\
\hline $\begin{array}{l}\text { 2BV11BT03 } \\
5\end{array}$ & 3 & 3 & 4 & 3 & 4 & 17 \\
\hline $\begin{array}{l}\text { 2BV11BT03 } \\
7\end{array}$ & 3 & 3 & 4 & 3 & 4 & 17 \\
\hline $\begin{array}{l}\text { 2BV11BT03 } \\
9\end{array}$ & 3 & 3 & 3 & 3 & 4 & 16 \\
\hline $\begin{array}{l}\text { 2BV11BT04 } \\
1\end{array}$ & 3 & 3 & 4 & 3 & 4 & 17 \\
\hline $\begin{array}{l}\text { 2BV11BT04 } \\
2\end{array}$ & 2 & 2 & 3 & 2 & 3 & 12 \\
\hline $\begin{array}{l}\text { 2BV11BT04 } \\
4\end{array}$ & 3 & 3 & 4 & 3 & 4 & 17 \\
\hline $\begin{array}{l}\text { 2BV11BT04 } \\
5\end{array}$ & 3 & 3 & 4 & 3 & 4 & 17 \\
\hline $\begin{array}{l}\text { 2BV11BT04 } \\
6\end{array}$ & 3 & 3 & 3 & 3 & 4 & 16 \\
\hline
\end{tabular}

\begin{tabular}{|c|c|c|c|c|c|c|}
\hline $\begin{array}{l}\text { 2BV11BT04 } \\
7\end{array}$ & 3 & 3 & 3 & 3 & 4 & 16 \\
\hline $\begin{array}{l}\text { 2BV11BT04 } \\
9\end{array}$ & 3 & 3 & 4 & 3 & 4 & 17 \\
\hline $\begin{array}{l}\text { 2BV11BT05 } \\
1\end{array}$ & 2 & 2 & 3 & 3 & 3 & 13 \\
\hline $\begin{array}{l}\text { 2BV11BT05 } \\
2\end{array}$ & 3 & 3 & 3 & 3 & 4 & 16 \\
\hline $\begin{array}{l}\text { 2BV11BT05 } \\
3\end{array}$ & 3 & 3 & 3 & 3 & 4 & 16 \\
\hline $\begin{array}{l}\text { 2BV11BT05 } \\
4\end{array}$ & 4 & 3 & 4 & 4 & 4 & 19 \\
\hline $\begin{array}{l}\text { 2BV11BT05 } \\
5\end{array}$ & 3 & 3 & 3 & 3 & 4 & 16 \\
\hline $\begin{array}{l}\text { 2BV11BT05 } \\
8\end{array}$ & 3 & 3 & 3 & 3 & 4 & 16 \\
\hline $\begin{array}{l}\text { 2BV11BT05 } \\
9\end{array}$ & 3 & 3 & 3 & 3 & 4 & 16 \\
\hline $\begin{array}{l}\text { 2BV11BT06 } \\
1\end{array}$ & 4 & 4 & 3 & 4 & 4 & 19 \\
\hline $\begin{array}{l}\text { 2BV11BT06 } \\
2\end{array}$ & 3 & 3 & 3 & 3 & 4 & 16 \\
\hline Total & 140 & 139 & 157 & $\begin{array}{r}14 \\
4\end{array}$ & 169 & \\
\hline Average & $\begin{array}{r}3.11 \\
1 \\
\end{array}$ & $\begin{array}{r}3.08 \\
8\end{array}$ & $\begin{array}{r}3.48 \\
8 \\
\end{array}$ & 3.2 & $\begin{array}{r}3.75 \\
5 \\
\end{array}$ & $\begin{array}{r}16.64 \\
4 \\
\end{array}$ \\
\hline
\end{tabular}

Table 2: Marks obtained by individual student for each PI

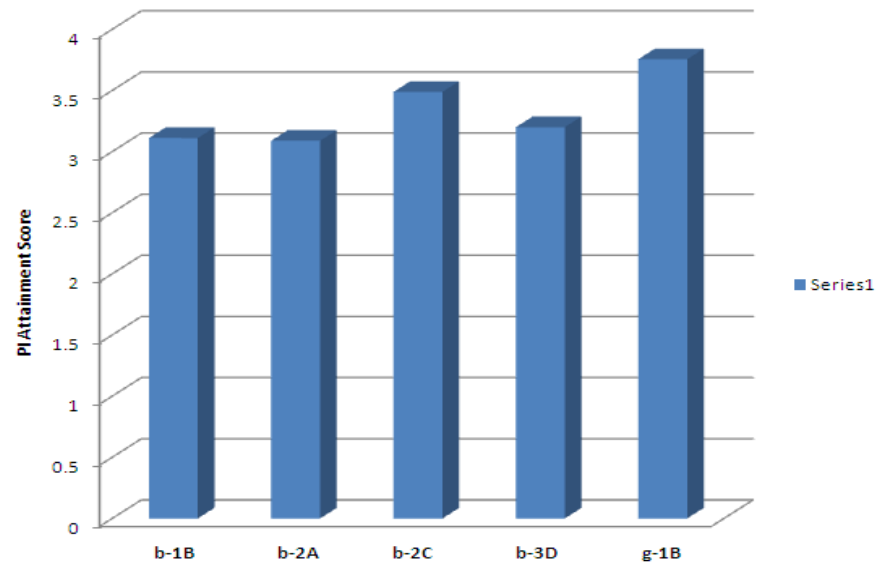

Figure 1: Score obtained for PIs in consideration

Students were able to perform the open-ended experiment by selecting appropriate equipments and tools to meet the desired needs of the task and were also able to follow correct operating procedures. From this open-ended experiment students were able to connect the relation between Fermentation technology laboratory to that of Downstream Process Technology laboratory. This helps students to understand the flow of Bioprocess Engineering.

Students were assessed based on ABET's 3b criteria, where students were assessed and attainment on 
criteria $3 b$ was done in order to check the understanding of students and criteria $3 \mathrm{~b}$ was assessed using the above rubrics and attainment was found to be $8.25 \%$ out of $10 \%$. The attainment was found to be satisfactory.

Students were assessed based on ABET's $3 \mathrm{~g}$ criteria, where students were assessed and attainment on criteria $3 \mathrm{~g}$ was done in order to check how students write their report and conclude the results and criteria $3 \mathrm{~g}$ was assessed using the above rubrics and attainment was found to be $9.35 \%$ out of $10 \%$, which was excellent.

At the end students were made to share the results with other groups in order to check their results. This will make students to come to know which downstream method has given accurate results and it was found that Ultrafiltration used to purify the enzyme provided better results compared to other downstream methods. Authors find that handling big teams (More number of students in a group) is a challenge for assessment and hence in future more groups with less number of students in each group can be formed for open-ended experiments.

\section{References}

[1] Evans, D.L., McNeill, B.W., and Beakley, G.C., "Design in Engineering Education: Past Views of Future Directions," Journal of Engineering Education, Vol. 79, No. 4, 1990, pp. 517-522.

[2] Dutson, A.J., Todd, R.H., Magleby, S.P., and Sorensen, C.D., "AReview of Literature on Teaching Design Through Project-OrientedCapstone Courses," Journal of Engineering Education, Vol. 76, No. 1, 1997,pp. 17-28.

[3] Dym, C.L., "Teaching Design to Freshmen: Style and Content," Journal of Engineering Education, Vol. 83, No. 4, 1994, pp. 303-310.

[4] Dym, C.L., and Little, L., Engineering Design: A Project-Based Introduction, $3^{\text {rd }}$ ed., New York, N.Y.: John Wiley, 2003.

[5] Dym, Alice, Ozgur, Daniel and Larry, "Engineering Design Thinking, Teaching, and Learning," Journal of Engineering Education, Vol. 94, No.1, 2005, pp. 103-120.

[6] Nagaraj Ekabote \& K.G.Kodancha, "Teaching and Learning Engineering Design: A PBL Approach," NGEEE International Conference, SR Engineering College, Warangal, 2013-14.

[7] Nagaraj Ekabote and Krishnaraja G. Kodancha, "The Role of Tutorials in Engineering Design Course", Journal of Engineering Education Transformations, Vol. 28, No. 2 and 3, 2015, pp. 25-29.
[8] Louis L. Bucciarelli (2002) "Between Thought and Object in Engineering Design," Journal of Design Studies, Elsevier Science Ltd, Vol. 23, Issue 3, pp. 219-231.

[9] Julie E Mills and David F Treagust(2003) "Engineering Education- Is Problem Based or Project Based Learning the Answer", Australasian Journal of Engineering Education (AAEE), ISSN 1324-5821.

[10] Hamid.A.Hadin and Sven.K.Esche (2002) "Enhancing the Engineering Curriculum through project based Learning", Proceedings of the ASEE/IEEE Frontiers in Education Conference, Boston, M.A.

[11] Peter D. Hiscocks (2005) "Project-Based-Learning: Outcomes, Descriptors and Design", Proceedings of the Canadian Engineering Education Association.

[12] C.R. Johnston, D.J. Caswell, D.M. Douglas, M.J. Eggermont (2004) "A Competency-Based, StudentCentered Assessment Model for Engineering Design", proceedings of the Canadian Engineering Education Association.

[13] Richards, L.G., and Carlson-Skalak, S(1997) "Faculty Reactions to Teaching Engineering Design to First year Students" , Journal of Engineering Education, Vol. 86, No. 3, pp. 233-292.

[14] Yousef Haik (2003) "Engineering Design Process", First edition, New Delhi, Cengage Learning India Private Limited.

[15] Dym, C.L., and Little, L (2003) "Engineering Design: A Project-Based Introduction", $3^{\text {rd }}$ ed., New York, N.Y.: John Wiley.

[16] Monica.R.Cardella, Cynthia.J.Atman and Robin.S.Adams (2006) "Mapping between Design Activities and External Representations for Engineering Student Designers", Design Studies, Volume 27, No.1, pp. $5-24$.

[17] Gay Lemons, Adam Carberry, Chris Swan and Chris Rogers (2010) "The Benefit of Model Building in Teaching Engineering Design" Journal of Design Studies, Elsevier Ltd, Vol. 31, Issue 3, pp. 288-309. 